\title{
THE BIBLICAL DATE OF MAN'S CREATION.
}

Sir, - A correspondent's enquiry in your July number, as to the authority for the date of man's creation on the earth being placed at about 4,000 years before the Christian era, deserves, I humbly think, an answer rather clearer and more to the point than is contained in Mr. L. Horner's somewhat lengthy discourse on this subject. That gentleman does not seem to be aware that there have been later commentators and critics on the chronology of the Bible than Arch. bishop Usher : such as Ffynes-Clinton, Brown, and others, whose industry as well as acumen on such subjects it is simply ridiculons to ignore. As these authors plainly show, any one may, without much trouble, verify for himself the period of 4,000 years, or thereabouts, from the dates and notices often supplied in the Bible itself. I give Ffynes Clinton's conclusions; but there are more modern works on the subject :-

From the creation (of man) to the flood

From the flood to the call of Abraham $\ldots \ldots \ldots \ldots \ldots \ldots . . . .$.

From this call and the Exodus from Egypt.............

In the Wilderness

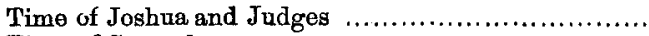

Time of Samuel

Time of the Kings and the captivity in Babylon .......

Duration of the captivity

1,656 years.

352 "

$430 \quad "$

40 ,

457 (A.) "

32 (B.) ,"

491

70

s)

Total.

The retum from this captivity took place soon after

the conquest of Babylon by Cyrus, King of Persia,

which is fixed, from profane history, at B.c.

\section{8,528 yఆars.}

\section{6}

Therefore, adding these together, we have, B.c. 4,064 years.

for the approximate date of the creation of man on the earth; I way approximate, because there are two slight gaps in the chronology, (marked A. and B. above), which cannot be filled up with absolute accuracy; but from internal evidence these could not have been much more than 40 years in duration; they may have been even less; I have here allowed that period for them. I may add that the first two periods in the above list are obtained by adding together the ages of the patriarchs before and after the flood, when the eldest son of each was born. The other dates are supplied, more or less, directly from the Bibleitself.

It is also to be observed that some of the other ancient manuscripts of the Scriptures give somewhat different periods from these : such e.g., as the Septuagint version, which adds 600 years more before the flood, and 600 more after it ; making therefore altogether between 5,200 and 5,300 years from the creation of man and the birth of Christ; and rather over 7,000 years to the present time; and other manuscripts give, I believe, even a more extended term that this; but the difference between them all is not very great, as compared, at least, with geological computations and estimates of time; and the question would turn on the comparative authority of the several manuscripts.

I do not see, therefore, that any one has a right to treat the received period of 4,000 .years, or thereabouts, as a mere figment or imagining of Usher, or any one else. As far as the authority of the Bible goes, (which is, at any rate, the most ancient written history in the world), 4,000 or 5,000 years (or on the largest compatation not much more), seems clearly fixed as the period which elapsed between man's first appearance on the earth, and the beginning of the Christian era.

$$
\begin{aligned}
& \text { I am, Sir, yours obediently, } \\
& \text { AN OLd SUbscriber. }
\end{aligned}
$$

